\title{
FACTORS THAT INFLUENCE THE CAREER PATH AND CAREER SATISFACTION OF A PHARMACY GRADUATE IN ROMANIA
}

\author{
DRAGOS FLORIAN CIOLAN ${ }^{1}$, CĂTĂLINA LILIANA ANDREI ${ }^{2 *}$, ANDREEA MIRICĂ $^{3}$, \\ IONELA ROXANA GLĂVAN ${ }^{3}$, DOINA DRĂGĂNESCU ${ }^{4}$, DUMITRU LUPULIASA ${ }^{1}$, RĂZVAN \\ MIHAI DOBRESCU ${ }^{5}$, FLAVIAN ȘTEFAN RĂDULESCU ${ }^{1}$
}

\author{
1 "Carol Davila" University of Medicine and Pharmacy, Centre for Drug Sciences (CedS), Bucharest, Romania \\ 2 "Carol Davila" University of Medicine and Pharmacy, Department of Cardiology and Thoracic Pathology, Bucharest, \\ Romania \\ ${ }^{3}$ Bucharest University of Economic Studies, Faculty of Economic Cybernetics, Statistics and Informatics, Statistics and \\ Econometrics Department, Bucharest, Romania \\ 4 "Carol Davila" University of Medicine and Pharmacy, Department of Pharmaceutical Physics and Informatics, Bucharest, \\ Romania \\ ${ }^{5}$ University Politehnica of Bucharest, Faculty of Entrepreneurship, Business Engineering and Management, Economics \\ Department, Bucharest, Romania
}

*corresponding author: ccatalina97@yahoo.com

${ }^{\#}$ Authors with equal contribution.

Manuscript received: April 2021

\begin{abstract}
Career and job satisfaction remain conspicuous factors both for managers and employees, essential for recruitment, retention and the overall organization's productivity and success. To investigate the factors that influence the career and job satisfaction among the community of pharmacy graduates, a questionnaire was conceived. The sample includes 340 respondents which filled the questionnaire between mid-February 2021 and mid-March 2021. The main objective of the present research was to investigate the degree of job satisfaction of Romanian pharmacy graduates and the factors that are associated with it. Logistic regression analysis was performed based on the questionnaire dataset. The obtained results indicate that recent graduates most probably pursue residency and have a job in the same time. Despite that, the extent postgraduate studies correspond to the job description as well as higher monthly income increases the likelihood a person is satisfied with job.
\end{abstract}

\section{Rezumat}

Satisfacția cu privire la locul de muncă precum și cea legată de carieră reprezintă factori esențiali pentru recrutare și angajare, dar şi pentru productivitatea şi succesul organizației. Pentru a investiga factorii care influențează satisfacția cu privire la carieră şi locul de muncă, în cazul absolvenților facultăţilor de farmacie, a fost conceput un studiu pe bază de chestioanar. Eșantionul include 340 de repondenți care au completat chestionarul în perioada februarie 2021 - martie 2021. Principalul obiectiv al studiului a fost să analizeze gradul de satisfacție al licențiaților în Farmacie din România și factorii de influență. În acest sens, s-a utilizat metoda regresiei logistice, aplicată pe datele de chestionar. Rezultatele au indicat faptul că absolvenții ultimei promoții aleg să continue studiile cu cele postuniversitare de rezidențiat, dar să aibă și un loc de muncă în sectorul privat în același timp. De asemenea, în urma studiului, s-a constatat că gradul de similitudine al postului cu specialitatea studiilor și venitul lunar influențează semnificativ satisfacția cu privire la locul de muncă.

Keywords: pharmacy, graduates, career path

\section{Introduction}

The lack jobs for the young university graduates reflect the recent decrease in the medium qualified-jobs. To this, tendency technological advances contributed significantly [6]. Nonetheless, compared to the IT sector, related studies show an increase in vacancies for many jobs in health and care supporting staff (World Economic Forum, 2020). For all aforementioned jobs the expected competences include computer literacy and office software proficiency. LinkedIn (2021) analysed jobs trends from its "Job on the
Rise" report for 15 countries world-wide [10]. For a first job or new opportunity on the labour market, the LinkedIn's predictions highlight position in ecommerce, healthcare or digital content as being in demand this year. As World Economic Forum (2020) noted in their report, the pandemic-related disruptions in 2020 have led to a particular global urgency and need for new technology job roles [21]. In addition, increasing demand for care economy jobs can point to new ways in which young professionals can achieve their career path. One study by the National Intelligence Council [13] estimates that automation 
may affect a share of the workforce and may require requalification. Also, their research pointed out that access to continued education may influence the way countries respond to these labour-market disruptions. Moreover, developing economies are likely to be more susceptible in providing education and proper training for the new graduated sector of the workforce.

Big data technology process is crucial for companies within the Healthcare and Pharmaceutical industry that want to sustain their competitiveness and strive for a better market position. In their study, Pesqueira, Sousa and Rocha highlight that, in order to adapt their employee skills to big data, the main goal of organizations operating in Healthcare and Pharmaceuticals should be tracking novel big data skills [14]. The medical Internet of Things, a concept introduced by Industry 4.0, demonstrates their advantages on intelligently connect the healthcare systems. For example, Reinhardt et al. studied the adoption and integration of 4.0 concept in the modernisation of the pharmaceutical and biopharmaceutical industries in Ireland [16]. The research reveals variations in knowledge for the 4.0 concept based on seniority, function and industry. However, Industry 4.0 is still in pole position and its roadmap is not fully drawn [18].

Judge, Heller and Mount highlights that a good career planning along with all related traits leads to happiness in life and job satisfaction among individuals [8]. Zhang et al. describe career intention among finalyear pharmacy undergraduate students in China and identify driving factors, such as gender, family background, psychological self-gratification and employment guidance [22]. By looking into the pharmacy student's behaviour, McEwen Smith et al. analysed the factors associated with their choice of pre-registration training programmes [12]. Their research revel that most pharmacy students in England and Wales emphasise long-term career aspiration to be very important when they select the pre-registration training programs providers. Moreover, McCarthy and Weber argue that the motivational factor that stands behind pharmacy students pursue of residency and training programs are the main drivers for a certain career path [11]. Nonetheless, the obtained income presents strong influence over the long-term aspirations. Ives et al. point out that students become aware of the importance of career development strategies early as from college [7]. According to a recent study in Estonia, students' feedback on competency-based pharmacy education highlights the need to pay more attention to the development of digital and transferable skills in regard to qualitative continuous development of future pharmacists [19]. Findings from Wilby and Rainkie reveal that pharmacy programs may have to carefully address the way they position the profession in their recruitment strategies [20].

Given this context, the aim of this paper is to perform an analysis, to understand what are the main determinants of pharmacy graduates career path in Romania, as well the factors that influence their job satisfaction with regard to professional development. An important aspect of this research is also the sociopolitical point of view. Recent public policies could influence young pharmacists' job satisfaction as well as their income.

\section{Materials and Methods}

\section{Methodology}

For the purpose of this paper a questionnaire aimed at pharmacy graduates was conceived (Table I). The questionnaire was distributed through the College of Pharmacists from Romania (CPhR) and the on-line platforms implemented by the Faculty of Pharmacy ("Carol Davila" University of Medicine and Pharmacy, Bucharest, Romania), between mid-February 2021 and mid-March 2021 and it consists of 14 questions addressing the following items: the year of graduation; the extent the field of study at bachelor and postgraduate level corresponds to the job description; number of interviews attended; professional competencies, soft skills, internships; graduates' career path; overall job satisfaction; respondents' satisfaction with respect to income; and sex, age and approximate monthly income.

The year of graduation was considered to be important because any graduate in pharmacy can apply for residency (Government Ordinance 18/29 August 2009, modified to date) at any time after becoming a bachelor [5]. The time interval between graduation and application for residency is potentially driven by their skills acquired during the faculty years and after graduation, as well as their personal experience on the labour market (career path) and the requirement of the employer. Age and sex were collected because these two variables often represent predictors for job satisfaction [15]. Moreover, age at graduation and could be an important factor for the decision to continue the education and for the option for a specialization domain, as it may partially reflect the dynamics of the pharmaceutical market. It appears to be a significant correlation between the approximate level of income and job satisfaction [2]. Thus, the respondents were requested to provide an approximation of their current monthly income. 
FARMACIA, 2021, Vol. 69, 5

Table I

The questionnaire made for the pharmacy graduates

\begin{tabular}{|c|c|c|}
\hline No. & Item & Answers \\
\hline \multirow{6}{*}{1.} & \multirow{6}{*}{ Year of graduation } & 2015 \\
\hline & & 2016 \\
\hline & & 2017 \\
\hline & & 2018 \\
\hline & & 2019 \\
\hline & & 2020 \\
\hline \multirow{5}{*}{2.} & \multirow{5}{*}{$\begin{array}{l}\text { The extent bachelor degree provided } \\
\text { knowledge suitable for employment }\end{array}$} & not at all \\
\hline & & not so much \\
\hline & & to some extent \\
\hline & & very much \\
\hline & & totally \\
\hline \multirow{5}{*}{3.} & \multirow{5}{*}{$\begin{array}{l}\text { The extent mandatory internship was } \\
\text { useful in finding a job }\end{array}$} & not at all \\
\hline & & not so much \\
\hline & & to some extent \\
\hline & & very much \\
\hline & & totally \\
\hline \multirow{4}{*}{4.} & \multirow{4}{*}{$\begin{array}{l}\text { Number of interviews attended until a job } \\
\text { was found }\end{array}$} & 1 \\
\hline & & 2 \\
\hline & & 3 \\
\hline & & 4 or above \\
\hline \multirow{4}{*}{5.} & \multirow{4}{*}{ Option after graduation } & continuing studies through residency and obtaining a job \\
\hline & & continuing studies through residency \\
\hline & & continuing studies with a Master or PhD programme and obtaining a job \\
\hline & & obtaining a job \\
\hline \multirow{5}{*}{6.} & \multirow{5}{*}{$\begin{array}{l}\text { The extent bachelor domain and job } \\
\text { correspond }\end{array}$} & not at all \\
\hline & & not so much \\
\hline & & to some extent \\
\hline & & very much \\
\hline & & totally \\
\hline \multirow{5}{*}{7.} & \multirow{5}{*}{$\begin{array}{l}\text { The extent post-graduate studies and job } \\
\text { correspond }\end{array}$} & not at all \\
\hline & & not so much \\
\hline & & to some extent \\
\hline & & very much \\
\hline & & totally \\
\hline \multirow{5}{*}{8.} & \multirow{5}{*}{$\begin{array}{l}\text { Competencies that are not fully covered } \\
\text { during bachelor studies }\end{array}$} & Accounting \\
\hline & & Communication \\
\hline & & computer literacy \\
\hline & & marketing \\
\hline & & professional level of a second language \\
\hline \multirow{5}{*}{9.} & \multirow{5}{*}{$\begin{array}{l}\text { Perceived benefit of assimilating non- } \\
\text { mandatory internships with mandatory } \\
\text { internships }\end{array}$} & not at all \\
\hline & & not so much \\
\hline & & to some extent \\
\hline & & very much \\
\hline & & totally \\
\hline & & not at all satisfied \\
\hline & & not so satisfied \\
\hline 10. & Job satisfaction regarding protessional & somehow satisfied \\
\hline & & very satisfied \\
\hline & & totally satisfied \\
\hline & & not at all satisfied \\
\hline & & not so satisfied \\
\hline 11. & Job satisfaction regarding income & somehow satisfied \\
\hline & & very satisfied \\
\hline & & totally satisfied \\
\hline 12 & Sex & male \\
\hline 12. & Sex & female \\
\hline 13. & Age (years) & Open item \\
\hline 14. & Approximately monthly income (RON) & Open item \\
\hline
\end{tabular}


With regard to graduates' career path, four possibilities were identified: continuing studies through residency and obtaining a job, continuing studies through residency, continuing studies with a Master or $\mathrm{PhD}$ programme and obtaining a job, obtaining a job. In order to assess the main determinants of a career path of for pharmacy graduates, a logistic regression has been performed.
The dependent variable takes the value 1 if the person choses to continue the studies through residency and have a job simultaneously and 0 otherwise. This approach is based on the fact 153 out of 340 respondents chose this kind of career path. Several logistic regression models using the questionnaire data were applied until a valid one with significant coefficients was obtained.

$$
\begin{gathered}
\log \left(\frac{p}{1-p}\right)=c+a_{1} \text { Number of interviews attended }+a_{2} \text { Year of graduation }+\varepsilon \\
p=\left\{\begin{array}{r}
1 \text { if the person chooses to continue the studies through residency and have a job simultaneously } \\
0 \text { if the person chooses any other option }
\end{array}\right.
\end{gathered}
$$

Job satisfaction was classified into two categories as follows: the variable takes value 1 if the person is satisfied or very satisfied with his/her professional development and 0 otherwise. Next, a logistic regression model was applied for identification of the determinants for job satisfaction with regard to professional development opportunities:

$$
\begin{gathered}
\log \left(\frac{q}{1-q}\right)=c+b_{1} \text { The extent postgraduate studies correspond to the job description }+b_{2} \text { Monthly income }+\varepsilon \\
q=\left\{\begin{array}{c}
1, \text { if the person is satisfied or very satisfied with regard to his or her professinal opportunities } \\
0, \text { otherwise }
\end{array}\right.
\end{gathered}
$$

\section{Results and Discussion}

The sample of this study consisted of 309 females and 31 males, mostly less than 30 years old. Considering job satisfaction by career path (Figure 1), approximately $40 \%$ of those who chose to continue their studies through residency are satisfied or very satisfied with their career path. The results are similar for those who choose to have a job and continue their studies through residency. However, graduates who chose to have a job only slightly less satisfied while those who combine master or PhD studies with a job are more satisfied. As pharmacy residency is a form of paid professional training ensured by the Romanian government [5], this offers both financial security and opportunity for continued education.

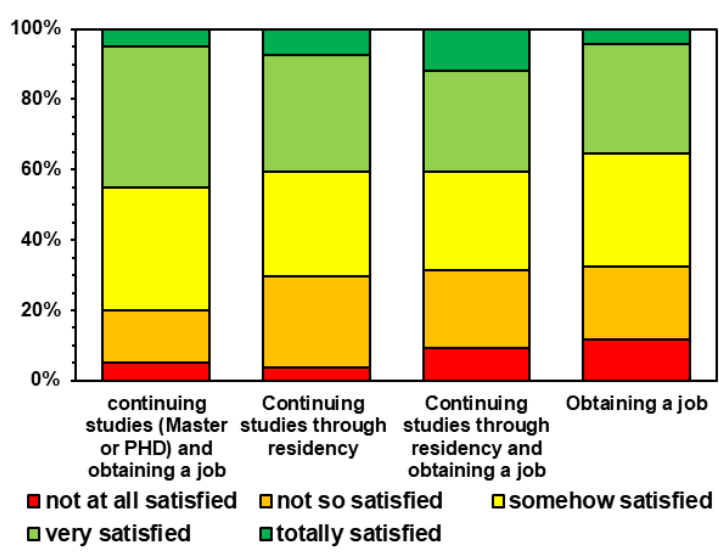

Figure 1.

Job satisfaction by career path

Figure 2 shows graduates' satisfaction with regard to the income by career path. Approximately $30 \%$ of those who chose to have job or to combine a job with residency or master and $\mathrm{PhD}$ studies are satisfied or very satisfied with regard to their income. Almost half of those who continued their studies through residency chose are satisfied or very satisfied with their income. These results might be due to the fact that the income for pharmacy residents increased with approximately $25 \%$ in 2020 compared to 2017 [9].

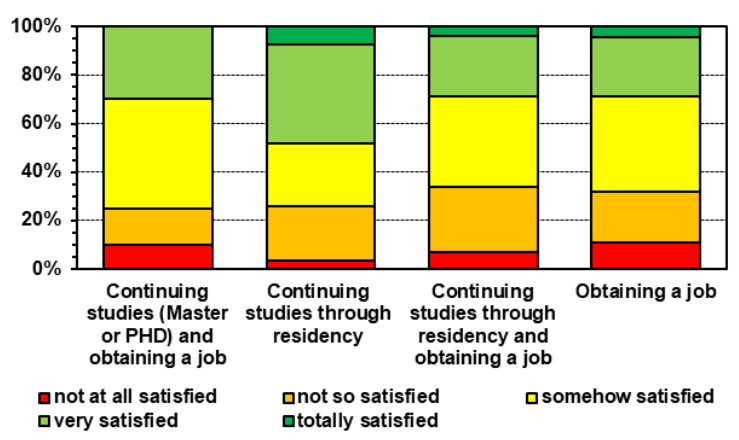

Figure 2.

Income satisfaction by career path

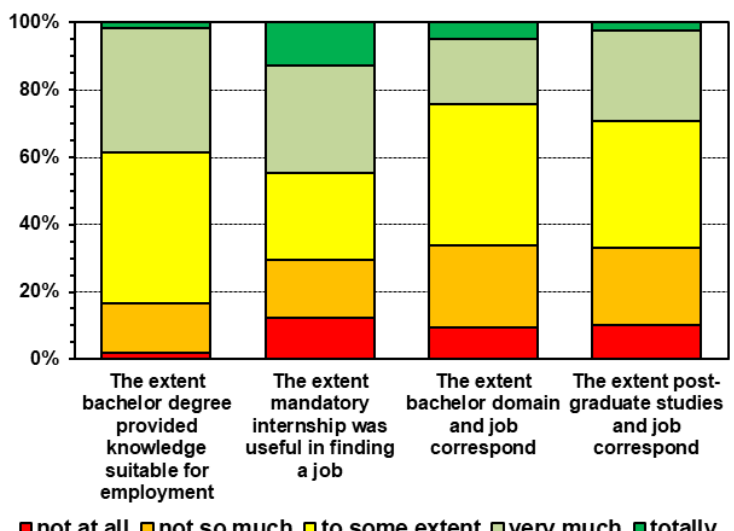

Figure 3.

Overall perception with regard to job and studies

The study caught the overall perception of graduates regarding job and studies (Figure 3). Most of the 
graduates consider that their bachelor studies provided them suitable knowledge for their job only to some extent, while most of them have jobs with a different profile than their specialization. However, the response clearly confirms that mandatory internship during studies was useful or very useful in finding a job. This finding is consistent with previous research. For example, Andrei et al. concluded that internships are key elements for pharmacy students' initial training and significantly increase chances to get a first job [1].

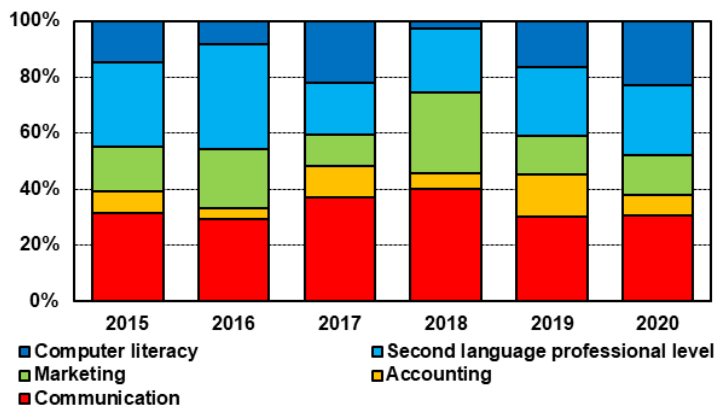

Figure 4.

Competencies not sufficiently covered during studies, by year of graduation

The assessment of the opinion on the competencies in relation with the year of graduation of the respondent indicated that they are not sufficiently covered during studies (Figure 4). Most of the respondents mentioned communication followed by a second language at professional level and computer literacy. This finding is in line with the conclusions of Ciolan et al., which stated that several additional competencies need to be covered by pharmacy curriculum: negotiation skills, supply chain, price settings and communication [4]. Also, Cerbin-Koczorowska et al. pointed out those pharmacy students should gain inter-professional skills as well, especially during postgraduate studies [3]. The share of graduates that are satisfied or very satisfied increased significantly in 2020 compared to the two previous years for both variables. An increase in the share of graduates that are to some extent satisfied is observed both in 2019 and 2020 (Figure 5) compared with 2016 - 2017 period.

However, the share of graduates that are to some extent satisfied is higher in 2015. The share of graduates that are not satisfied in regard to the income shows a considerable decrease particularly in 2020 compared with previous year.

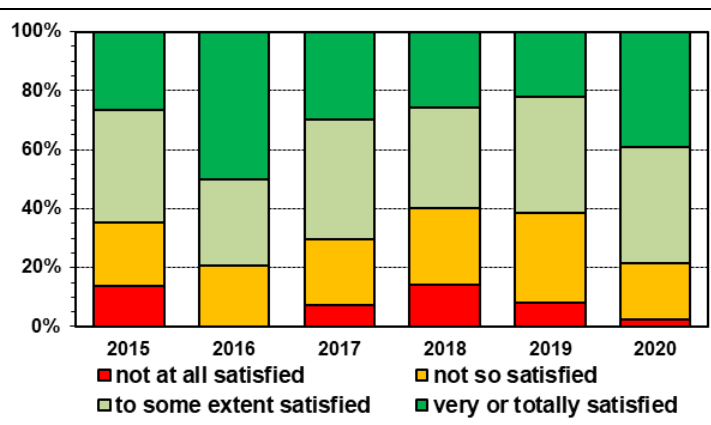

Figure 5.

Income satisfaction by year of graduation

Figure 6 present graduates' overall job satisfaction and shows that the share of graduates that are very or totally satisfied approximately doubled in 2020 compared with 2019 and exceeds the share from 2015. Clearly, in terms of the overall job satisfaction, the share of graduates that are to some extent satisfied is higher in 2020 compared with previous four years.

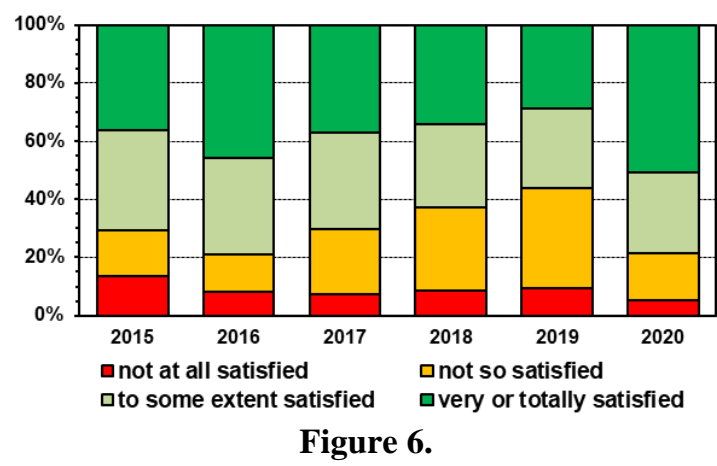

Overall job satisfaction by year of graduation

Equation 1 presents the results of the logistic regression model applied for the assessment of the main determinants of a career path of pharmacy graduates. The HosmerLemeshow test shows that the logit model is suitable for modelling the dependent variable while the LR test that the model is valid. $71.47 \%$ of the observations were correctly assigned to the dependent variable. Both coefficients are significant at $10 \%$ level. The model reveals that the more interviews a person attends, the more likely is to continue the studies through residency and have a job simultaneously. Moreover, the likelihood of choosing such a career path increases as the year of graduation increase. More specifically, recent graduates most probably pursue residency and have a job in the same time.

$$
\begin{gathered}
\log \left(\frac{p}{1-p}\right)=-1163.8+0.22 \text { Number of interviews attended }+0.57 \text { Year of graduation (1) } \\
p=\left\{\begin{array}{r}
1 \text { if the person chooses to continue the studies through residency and have a job simultaneously } \\
0 \text { if the person chooses any other option } \\
z_{\text {Number of interviews attended }}=1.78, z_{Y \text { ear of graduation }}=8.37
\end{array}\right.
\end{gathered}
$$


Model specificity $=71.12 \%$; Model Sensitivity $=71.9 \%$; Overall \% Correct $=71.47 \%$.

$\mathrm{H}-\mathrm{L}$ Statistic $=4.37$; Prob Chi-Sq $=0.8214 ; \mathrm{LR}$ Statistic $=91.5 ;$ Prob $($ LR Statistic $)=0.00$.

Equation 2 presents the results of the logistic regression model aimed at understanding the main factors that influence job satisfaction with regard to professional opportunities. As one can observe, the HosmerLemeshow test shows that the logit model is suitable

$$
\begin{gathered}
\log \left(\frac{q}{1-q}\right)=-3.1+0.36 \text { The extent postgraduate studies correspond to the job description } \\
+0.0003 \text { Monthly income }(2) \\
q=\left\{\begin{array}{c}
1, \text { if the person is satisfied or very satisfied with regard to his or her professinal opportunities } \\
0, \text { otherwise }
\end{array}\right. \\
z_{\text {The extent postgraduate studies correspond to the job description }}=2.7, z_{\text {Monthly income }}=4.35
\end{gathered}
$$

Model specificity $=88.1 \%$; Model Sensitivity $=34.7 \%$; Overall \% Correct $=68.4 \%$.

$\mathrm{H}-\mathrm{L}$ Statistic $=4.9$; Prob Chi-Sq $=0.75 ; \mathrm{LR}$ Statistic $=33.6 ;$ Prob $($ LR Statistic $)=0.00$.

\section{Conclusions}

Career path development and job satisfaction are significantly influenced by extrinsic factors. Pharmacy graduates may be more satisfied with the job they have as long as the income increases, in particularly among those with extent postgraduate studies correspond to the job description. In this respect, for this very reason they chose certain type of jobs or engage in a specific activity that offer the possibility of increasing the income.

1214 places for Residency in Units subordinated to the Ministry of Health and local public authorities, session 15.11.2020, were available [17]. The number increased compared to 2019 (714 places) and also compared to previous years (225 places in 2018, 129 places in 2017 and 126 places in 2016). Regarding the specialities available, in 2020 there were 4 specialities compared with 2016 (only 2).

The share of graduates that are very or totally satisfied almost doubled in 2020 compared with 2019. The share of graduates that are to some extent satisfied is higher in 2020 compared with previous four years. The explanatory memorandum of the $\mathrm{CPhR}$ (College of Pharmacists from Romania) no 1878/29.07.2019 had a positive influence on the adoption of a public policy that clearly proved to be effective.

Overall, further research in this area is still needed to guide the understanding of factors that influence the job and career satisfaction of pharmacy graduates.

\section{Conflict of interest}

The authors declare no conflict of interest.

\section{References}

1. Andrei CL, Ciolan DF, Mirica A, Toma IE, Draganescu D, Radulescu FS, Internships and the for modelling the dependent variable while the LR test shows that the model is valid. $68.2 \%$ of the observations were correctly assigned to the dependent variable. Both coefficients are significant at $1 \%$ level. The extent postgraduate studies correspond to the job description as well as higher monthly income increases the likelihood a person is satisfied or very satisfied with his/her job. next generation of pharmacists in Romania. Farmacia, 2019; 67(2): 378-382.

2. Bakan I, Buyukbese AT, The relationship between employees' income level and employee job satisfaction: An empirical study. Int J Business Soc Sci., 2013; 4(7): 18-25.

3. Cerbin-Koczorowska M, Przymuszała P, Michalak M, Piotrowska-Brudnicka SE, Kant P, Skowron A, Comparison of medical and pharmacy students' readiness for interprofessional learning - A crosssectional study. Farmacia, 2020; 68(6): 1166-1172.

4. Ciolan DF, Andrei CL, Mirică A, Toma IE, Drăgănescu D, Rădulescu FS, Internships in pharmaceutical students' development. Farmacia, 2020; 68(1): 176184.

5. Government Ordinance 18/29 August 2009, modified to date, https://rezidentiat.ms.ro/legislatie/ordonanta nr_18_2009.pdf.

6. International Labour Organisation, Global Employment Trends for Youth 2020: Technology and the future of jobs International Labour, www.ilo.org/wcmsp5/groups/ public/---dgreports/---dcomm/---publ/documents/ publication/wcms_737648.pdf.

7. Ives RC, Klein KC, Mason NA, Career and professional development services for pharmacy students. Curr Pharm Teach Learn., 2020 ;12(9): 1110-1115.

8. Judge T, Heller D, Mount M, Five-factor model of personality and job satisfaction: A meta-analysis. $J$ Appl Psychol., 2002; 87(3): 530-541.

9. Law number 51/27 April 2020, http://legislatie.just.ro/ Public/DetaliiDocumentAfis/225050.

10. LinkedIn, 2021; The fastest-growing jobs in the world, https://business.linkedin.com/talent-solutions/ emerging-jobs-report\#all.

11. McCarthy BC, Weber LM, Update on factors motivating pharmacy students to pursue residency and fellowship training. Am J Health Syst Pharm., 2013; 70(16): 1397-1403.

12. McEwen Smith L, Price MJ, Fleming G, Swanwick T, Hirsch C, Yahyouche A, Ward J, Buckely S, Paudyal V, How do pharmacy students select their pre-registration training providers? A mixed methods evaluation of the national recruitment scheme in England and Wales. Int J Pharm Pract., 2020; 28(4): 370-379. 
FARMACIA, 2021, Vol. 69, 5

13. NIC, 2021; Global Trends report: Global Trends 2040: A More Contested World, www.dni.gov/files/ODNI/ documents/assessments/GlobalTrends_2040.pdf.

14. Pesqueira A, Sousa MJ, Rocha Á, Big data skills sustainable development in healthcare and pharmaceuticals. J Med Syst., 2020; 44(11): 197: 1-15.

15. Piosik A, Strojek-Filus M, Sulik-Górecka A, Szewieczek A, Gender and Age as Determinants of Job Satisfaction in the Accounting Profession: Evidence from Poland. Sustainability, 2019; 11(11): 3090: 1-24.

16. Reinhardt IC, Oliveira DJ.C, Ring DDT, Current perspectives on the development of industry 4.0 in the pharmaceutical sector. J Ind Inf Integr., 2020; 18(3): 100131: 1-11.

17. Residency in Units subordinated to the Ministry of Health and local public authorities session 15.11.2020, www.rezidentiat.ms.ro/20201115/index.html.

18. Rojas RA, Rauch E, Vidoni R, Matt D, Enabling connectivity of cyber-physical production systems: a conceptual framework. Procedia Manufact., 2017; 11: 822-829.

19. Volmer D, Sepp K, Raal A, Students' Feedback on the Development of a Competency-Based Pharmacy Education (CBPE) at the University of Tartu, Estonia. Pharmacy (Basel), 2021; 9(1): 45: 1-16.

20. Wilby KJ, Rainkie DC, Global comparison of professional positioning by pharmacy programs towards prospective students. Res Social Adm Pharm., 2020; 16(12): 1658-1663.

21. World Economic Forum, Future of Jobs Report 2020, www.3.weforum.org/docs/WEF_Future_of_Jobs_2 020.pdf.

22. Zhang T, Li L, Bian Y, Final-year pharmacy undergraduate students' career intention and its influencing factors: a questionnaire study in northwest China. BMC Med Educ., 2020; 20(1): 405: 1-10. 